\title{
The efficacy of exercise in preventing injury in adult male football: a systematic review of randomised controlled trials
}

Tom Porter ${ }^{*}$ and Alison Rushton

\begin{abstract}
Background: Injury prevention measures might reduce the impact of injury on footballers and football clubs. Increasing research has evaluated the use of exercise for injury prevention. However, research has focused on adolescent females. No high-quality systematic reviews have evaluated the efficacy of all forms of exercise on preventing injury in adult male football.
\end{abstract}

Objective: Our objective was to conduct a systematic review to evaluate the efficacy of exercise in preventing injury in adult male football.

Data sources: Comprehensive searches of electronic databases CINAHL (Cumulative Index to Nursing and Allied Health Literature), MEDLINE, Embase, AMED (The Allied and Complementary Medicine Database), the Cochrane Central Register of Controlled Trials, PEDro (The Physiotherapy Evidence Database), SPORTDiscus ${ }^{T M}$, the National Research Register, Current Controlled Trials website (York), and http://www.ClinicalTrials.gov were conducted using predefined search terms to identify relevant studies published up to 1 March 2013. Screening of references, searches of grey literature, and hand searches of relevant journals were also employed.

Study selection: Included studies were randomized controlled trials using injury incidence as an outcome measure to evaluate the efficacy of an exercise intervention on uninjured male footballers aged 16 years and over. Articles not written in English were excluded.

Data extraction: Two researchers independently searched data sources, screened studies for eligibility, evaluated risk of bias, and extracted data using predefined criteria.

Study appraisal and synthesis methods: Risk of bias of included trials was assessed using the Cochrane Collaboration's tool for assessing risk of bias. There was insufficient trial comparability (outcome measures, interventions, injury type) for meta-analysis, and a qualitative analysis was performed.

Results: Eight trials $(n=3,355)$ from five countries met the inclusion criteria. All trials were assessed as having a high risk of bias. Two trials reported statistically significant reductions in hamstring injuries with eccentric exercise, and two reported statistically significant reductions in recurrent ankle sprains with proprioceptive exercise. Four trials showed no statistically significant difference in injury incidence with exercise interventions targeting a range of injuries.

Limitations: Notable limitations of included trials included poor reporting and limited blinding. A high risk of bias and insufficient comparability across trials prevented quantitative data synthesis.

(Continued on next page)

\footnotetext{
* Correspondence: tomporter_@hotmail.com

School of Sport, Exercise and Rehabilitation Sciences, College of Life and

Environmental Sciences, University of Birmingham, Edgbaston, Birmingham B15 2TT, UK
} 
(Continued from previous page)

Conclusions: Limitations in the context of study quality and heterogeneity resulted in an inability to reach a clear conclusion regarding efficacy of exercise for injury prevention in adult male football. Future low risk of bias, properly powered, and comprehensively reported trials are warranted to evaluate the efficacy of exercise on injury prevention. The use of eccentric hamstring exercise for hamstring injury prevention and proprioceptive training for recurrent ankle sprain prevention might be a good focus for future trials, as existing trials with a high risk of bias suggest an effect.

\section{Key points}

- The use of eccentric hamstring exercise may be efficacious in hamstring injury prevention.

- Proprioceptive training may be efficacious in recurrent ankle sprain prevention.

- A lack of high-quality randomised controlled trials of injury prevention in the adult male football population is contradictory to the number of publications on injury epidemiology and risk factors in this population.

\section{Introduction}

\section{Rationale}

Football (soccer) has been described as the world's most popular sport, with over 265 million registered players [1]. Injury is a major factor influencing player availability up to the highest level of the sport $[2,3]$. Top European clubs have a mean of $14 \%$ of a squad unavailable due to injury at any one time, with players experiencing a mean of two injuries a season $[4,5]$. This could have a significant impact on team performance and results [6], which in turn could have financial implications for clubs $[7,8]$.

The impact of injury on footballers can be multifaceted. Injuries can result in a detraining effect, with loss of physiological adaptations and fitness, and may become psychological burdens for players $[9,10]$. Some injuries also have long-term implications, such as the risk of developing early-onset osteoarthritis [11]. This implies that injury prevention measures may benefit player wellbeing as well as enhancing a team's chance of success. Some clubs include exercises aimed at preventing injuries in their training [12].

There has recently been an increase in research evaluating the use of exercise to reduce the risk of injury to athletes. A number of studies demonstrate that neuromuscular training programs may reduce the risk of injury to females, particularly during adolescence [13-16]. A systematic literature review evaluating the prevention of non-contact anterior cruciate ligament (ACL) injuries with neuromuscular training in female athletes reported a prophylactic effect on injury incidence in all of the five included trials [17]. Interestingly, a meta-analysis evaluating the influence of exercise intervention on the risk of
ACL injury in a range of sports included trials with participants of both genders and concluded that injury prevention exercises that include a proprioceptive neuromuscular training component may be more effective in males, reporting a risk reduction of $52 \%$ in females and $85 \%$ in males [18]. This meta-analysis included eight trials; only one trial (a non-randomized controlled trial evaluating the efficacy of proprioceptive exercise on ACL injury incidence in male footballers) included male participants [19]. The absence of randomization in this trial introduced a risk of selection bias [20], and the predominantly female cohorts evaluated in the review limit extrapolation of the findings to males.

Two systematic reviews evaluate the use of exercise for injury prevention specific to football. Both review the efficacy of interventions on players of all ages and either gender. Kirkendall and Dvorak [21] included trials evaluating any exercise-based intervention and concluded that both specific and generic exercise interventions are effective in preventing injuries. The review used these findings to inform the development of an exercise warm-up program. However, the validity of the findings is limited, as the review had several methodological limitations [22]. Notably, the literature search was inadequately reported, narrow search terms were used, only one database was searched, there were no clear eligibility criteria for study selection, and the risk of bias of included trials was not assessed [22,23]. These limitations limit confidence in the review findings.

The more recent review by van Beijsterveldt et al. [24] excluded trials using injury- or joint-specific exercises and reviewed the efficacy of generic exercise interventions. Contradicting evidence of efficacy of these interventions was attributed to differences in study samples, design, and compliance. Included trials focused predominantly on adolescent female footballers. Four of the six included trials investigated only female participants, and one trial included only male participants. Five of the trials assessed footballers under the age of 19 years.

The high proportion of injury-prevention research in adolescent females is likely to be due to their increased risk of severe injury, such as ACL rupture [25-27]. Also, the positive influence of neuromuscular training has been attributed to improvements in kinematics of movement, which may be more apparent in females due to gender- 
related differences in limb biomechanics, neuromuscular/ strength imbalances, and hormonal influences [28-31]. These gender-related differences imply that injury-prevention research in female footballers may not be extrapolated to males. Males represent the largest group of participants in football, accounting for $90 \%$ of players internationally, and it has been reported that they may have an injury incidence similar to or higher than that of females [1,32,33]. There are currently no high-quality systematic reviews evaluating the efficacy of all forms of exercise intervention in reducing the risk of injury in adult male footballers.

\section{Objectives}

The objective of this systematic review is to evaluate the efficacy of exercise in preventing injury in adult male football.

\section{Methods}

This systematic review conforms to the Preferred Reporting Items for Systematic Reviews and Meta-Analyses (PRISMA) statement [22].

\section{Protocol}

This systematic review was completed according to predefined protocols that followed the method guidelines from the Cochrane Handbook [20] and the Centre for Reviews and Dissemination's Guidance for Undertaking Reviews in Healthcare [34].

\section{Eligibility criteria}

The following criteria were used to inform study selection, with reference to participants, interventions, comparators, outcomes, and study design (PICOS) [23,34].

\section{Studies}

Studies included were randomized controlled trials (RCTs) with at least one comparison group continuing with regular training. Limiting the comparison to regular training rather than non-exercise interventions allowed a pragmatic analysis of the efficacy of exercise used as an alteration or addition to regular training. Articles not written in English were excluded, rather than not included, to ensure that the risk of language bias could be assessed $[35,36]$. There were no restrictions on publication date up to 1 March 2013.

\section{Participants}

Male footballers competing at any level of adult football were included [37]. The age used for inclusion was 16 years, as adult teams often include players of this age [8,38-41]. This is also in accordance with the FIFA Laws of the Game, which are rules for players aged 16 and over and may be adjusted for those under 16 [37]. To ensure that the efficacy of exercise in injury prevention rather than rehabilitation was evaluated, only footballers uninjured at the start of a study were included. Mixed populations were included if there was a separate analysis of footballers meeting these criteria.

\section{Interventions}

Interventions were required to be exclusively exercise based. Studies assessing multiple interventions were included if there was a separate analysis of an exclusively exercise-based intervention.

\section{Outcome measures}

Included were outcome measures determining injury incidence. This could be a measure of injury rate or risk. Three often utilized measures of injury incidence are the incidence of injury per unit of athlete time (incidence rate), the number of injured athletes divided by the number of athletes at risk (epidemiologic incidence proportion), or the number of injuries divided by the number of athletes at risk (clinical incidence) [42].

\section{Information sources}

Electronic databases including CINAHL (Cumulative Index to Nursing and Allied Health Literature), MEDLINE, Embase, AMED (The Allied and Complementary Medicine Database), the Cochrane Central Register of Controlled Trials, PEDro (The Physiotherapy Evidence Database), SPORTDiscus ${ }^{\mathrm{Tm}}$, the National Research Register, Current Controlled Trials website (York), and http:// www.ClinicalTrials.gov were searched for relevant studies. The National Technical Information Service, System for Information on Grey Literature, and Index to Scientific and Technical Proceedings were searched for unpublished research [34]. All searches were conducted using sensitive search strategies to 1 March 2013.

\section{Literature search}

The search strategies were created by one reviewer and modified as required for each database. Table 1 demonstrates an example of search terms used. Screening of references listed in relevant systematic reviews and hand searches of journals that were the source of at least 10\% of the relevant articles were also employed. The searches were performed independently by two reviewers.

\section{Study selection}

The two reviewers independently screened the title and abstract of all identified studies, assessing the studies for inclusion using the grades 'eligible', 'may be eligible', or 'not eligible' [43] for each criterion on a standardized form. Studies that did not meet the inclusion criteria were excluded. If a study could not be unequivocally excluded, if there was disagreement between reviewers, or if there was insufficient information in the title and abstract, the full text of the study was obtained. The full texts were 


\section{Table 1 Example of a search strategy (the Medline OvidSP search)}

\begin{tabular}{|c|c|}
\hline 1 & (Football* OR Soccer).ti,ab \\
\hline 2 & $\exp$ FOOTBALL/ \\
\hline 3 & exp SOCCER/ \\
\hline 4 & 1 OR 2 OR 3 \\
\hline 5 & $\begin{array}{l}\text { (injur* OR ruptur* OR sprain* OR strain* OR disloc* OR accident* } \\
\text { OR trauma* OR tendin* OR tendon* OR tear* OR fractur* } \\
\text { OR break*).ti,ab }\end{array}$ \\
\hline 6 & $\exp$ WOUNDS AND INJURIES/ \\
\hline 7 & exp RUPTURE/ \\
\hline 8 & exp SPRAINS AND STRAINS/ \\
\hline 9 & $\exp$ ACCIDENTS/ \\
\hline 10 & exp TENDINOPATHY/OR exp TENDON INJURIES/ \\
\hline 11 & exp ATHLETIC INJURIES/ \\
\hline 12 & exp SOFT TISSUE INJURIES/ \\
\hline 13 & exp KNEE INJURIES/ \\
\hline 14 & exp FRACTURES, BONE/ \\
\hline 15 & $\exp$ ANKLE INJURIES/ \\
\hline 16 & exp HIP INJURIES/ \\
\hline 17 & $\exp$ BACK INJURIES/ \\
\hline 18 & $\begin{array}{l}5 \text { OR } 6 \text { OR } 7 \text { OR } 8 \text { OR } 9 \text { OR } 10 \text { OR } 11 \text { OR } 12 \text { OR } 13 \text { OR } 14 \text { OR } \\
15 \text { OR } 16 \text { OR } 17\end{array}$ \\
\hline 19 & $\begin{array}{l}\text { (exercis* OR neuromuscular OR proprio* OR strength* } \\
\text { OR stretch* OR "warm-up" OR balance OR flexibility OR training } \\
\text { OR intervention* OR kinesiotherapy OR program*).ti,ab }\end{array}$ \\
\hline 20 & $\begin{array}{l}\text { exp EXERCISE/OR exp EXERCISE MOVEMENT TECHNIQUES/OR } \\
\text { exp EXERCISE THERAPY/OR exp PLYOMETRIC EXERCISE/ }\end{array}$ \\
\hline 21 & $\begin{array}{l}\text { exp MUSCLE STRETCHING EXERCISES/OR exp PHYSICAL } \\
\text { EDUCATION AND TRAINING/ }\end{array}$ \\
\hline 22 & 19 OR 20 OR 21 \\
\hline 23 & $\begin{array}{l}\text { (prevent* OR protect* OR risk* OR reduc* OR avoid* } \\
\text { OR prehab* OR reccuren*).ti,ab }\end{array}$ \\
\hline 24 & exp ACCIDENT PREVENTION/ \\
\hline 25 & exp RECURRENCE/ \\
\hline 26 & 23 OR 24 OR 25 \\
\hline 27 & 22 OR 26 \\
\hline 28 & (trial* OR random* OR control* OR rct).ti,ab \\
\hline 29 & (trial* OR random* OR control* OR rct).pt \\
\hline 30 & exp RANDOMIZED CONTROLLED TRIAL/ \\
\hline 31 & 28 OR 29 OR 30 \\
\hline 32 & 4 AND 18 AND 27 \\
\hline 33 & 31 AND 32 \\
\hline
\end{tabular}

independently reviewed, and a study was included if both reviewers were satisfied that it met the eligibility criteria. If there was disagreement between the reviewers, agreement was sought by consensus after consulting the protocol, with a third reviewer mediating in the event of on-going disagreement. The level of agreement between reviewers was evaluated using Cohen's weighted $\kappa$ [44], and using the Landis and Koch criteria for interpretation [45].

\section{Data collection process}

Data from each included trial were independently extracted by the two reviewers using a standardized form based on the guidance in the Cochrane Handbook [20].

\section{Data items}

The extracted data included characteristics of the study and participants, details regarding interventions, outcome measures, duration until follow-up assessments, compliance, subject numbers, withdrawals, and intention to treat (ITT) analyses. For the purpose of this review, ITT analyses were defined as a complete assessment of outcomes of all randomized trial participants, regardless of withdrawal from the trial or adherence to the treatment regime [46]. This approach was taken because, without ITT analyses, there is potential for overoptimistic results of intervention efficacy [47].

\section{Risk of bias in individual studies}

The internal validity of the included trials was independently appraised by the two reviewers using the Cochrane Collaboration's tool for assessing risk of bias [20]. This tool was used as each of its domains is supported by empirical research, as is the use of the component rather than the scale approach $[20,48]$. This flexible, adaptive tool also fits well where the intervention cannot be blinded, as the potential influence of findings is considered in the appraisal. The reviewers used standardized forms to document each component of the risk-of-bias appraisal, and inter-observer agreement between reviewers was evaluated using Cohen's weighted $\kappa$ [44], again using the Landis and Koch criteria for interpretation [45]. If reviewers disagreed, agreement was sought by consensus after consulting the Cochrane tool guidance [20], with a third reviewer mediating in the event of on-going disagreement. Risk-ofbias scores were summarized in line with Rushton et al. [49]. The study selection and risk of bias assessment processes were initially piloted by the two reviewers.

\section{Summary measures}

If feasible, a common measure of injury risk reduction would have been used to facilitate data synthesis across trials with similar interventions.

\section{Synthesis of results}

Comparability of interventions, outcomes and timing of assessments, and risk of bias were considered to determine potential for appropriate quantitative synthesis of the trials. If the trials were sufficiently comparable and had a low risk of bias, meta-analyses would be performed and if not, a qualitative data synthesis produced. 


\section{Risk of bias across studies}

A summary of risk of bias across trials was tabulated, and the overall risk of bias was agreed by consensus. Differences in trial design, intervention, and outcome, and the inclusion of fewer than ten trials rendered it not helpful to produce a funnel plot to visualize potential publication bias $[20,34]$.

\section{Additional analyses}

If at least two trials were available with comparable study design, interventions, and outcomes, subgroup analyses would have been used to examine the implications of heterogeneity.

\section{Results}

\section{Study selection}

Eight trials from five countries were included [12,50-56]. Database and hand searches provided a total of 1,942 citations. After removal of duplicates, 763 remained. Following screening of titles and abstracts, 744 studies were excluded as they did not meet the eligibility criteria. Of the remaining 19 studies, attempts to obtain the full texts of two unpublished studies were unsuccessful. The full texts of the remaining 17 studies were reviewed. Of these, nine did not meet the inclusion criteria. The study selection flow diagram shows the number of studies at each stage of selection (Figure 1). Using weighted $\kappa$, substantial inter-reviewer agreement was achieved on trial inclusion (Cohen $\kappa$ 0.638, 95\% confidence interval [CI] -0.003 to $1.280)[44,45]$. Less than perfect agreement arose from the evaluation of one study due to the definition of injury. The study was included after discussion [51].

\section{Trial characteristics Methods}

Five trials investigated an exercise intervention group compared to a control group [50-54]. Two trials assessed exercise or orthotic intervention groups compared with a control group $[55,56]$. One trial divided participants into high- or low-risk subgroups for specific injuries and assigned the high-risk players to either an injury-specific exercise intervention group or a control group [12]. All control groups continued with their usual warm-up and training. Table 2 shows the main characteristics of the included trials.

\section{Participants}

The eight trials included a total of 3,355 participants meeting the eligibility criteria. Five trials [50-54] and 2,647 participants had no reported history of injury or increased risk of injury; 200 participants with a history of injury were recruited in two trials [55,56]. A further trial included assessment of 388 participants reported to be at high risk of injury [12].

\section{Interventions}

A range of exercise interventions were used, including specific targeted muscle strengthening and/or stretching [50-52,55], proprioceptive exercise $[55,56]$, and multi-faceted exercise intervention regimes [12,53,54]. Most trials used supervised exercise intervention as part of or in addition to regular training $[12,50,51,53,54]$. One trial used four supervised and then largely independent exercise sessions [52].

\section{Outcomes}

A range of injury types were assessed. Several trials investigated the incidence of specific injuries, including hamstring [50,52], ankle [55,56], Achilles and/or patellar tendon [51] or groin injuries [53]. Engebretsen et al. [12] assessed the incidence of injuries to the ankle, knee, groin, or hamstring, and van Beijsterveldt et al. [54] investigated all injuries.

Three trials reported a primary outcome on which a power calculation was based [50,53,54]. For each of these, the primary outcome was injury, defined as a physical complaint obtained during training or match play irrespective of the need for medical attention or time loss from football activities. This was also the main outcome of a further two trials $[51,55]$. The three remaining trials had a main outcome of time loss injuries, defined as an injury that results in a player missing training or match play $[12,52,56]$.

Table 2 demonstrates that measures used for reporting injury incidence varied. The use of time until first injury [53] and total number of injured players rather than number of injuries in two trials $[51,53]$ resulted in an inability to create a common measure of risk reduction for all of the trials. Several trials used further outcomes, including changes to athletic ability [52] and ultrasound assessment of structural changes to a tendon [51]. Other injury-related outcomes, such as severity of injury, were used by a number of trials $[12,50,51,54]$.

\section{Risk of bias within studies}

Using weighted $\kappa$, moderate inter-reviewer agreement was achieved on evaluating trial risk of bias (Cohen $\kappa$ 0.602 , 95\% CI $0.402-0.788$ ), with $100 \%$ agreement following discussion $[44,45]$. All eight trials were evaluated as high risk of bias (Table 3), which impacts on the interpretation of results [20].

\section{Results of individual studies}

Two of the four trials reporting a statistically significant reduction in injury related to hamstrings. Each showed a significantly lower incidence of hamstring strain with eccentric exercise intervention. Petersen et al. [50] reported 3.8 acute hamstring injuries per 100 player seasons in the intervention group and 13.1 in the control group (rate 


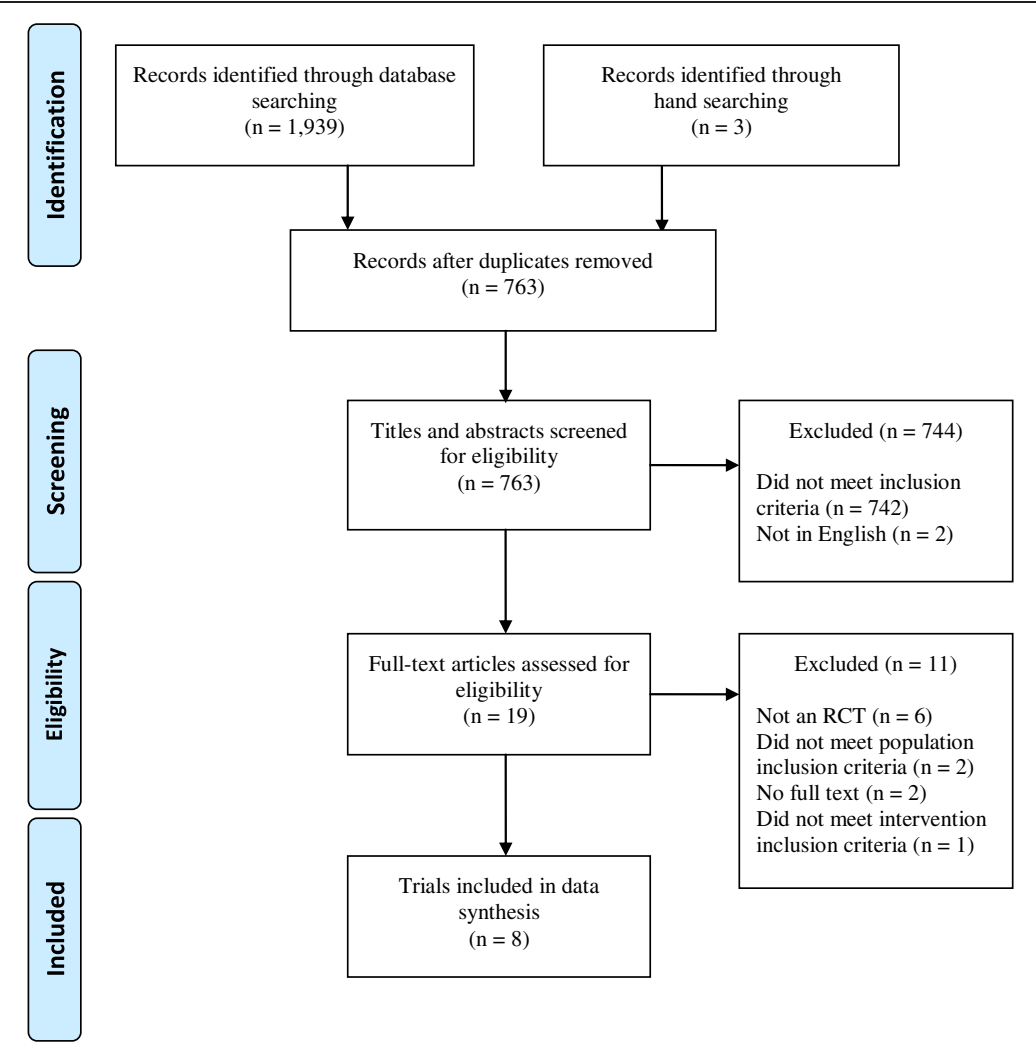

Figure 1 Study selection flow diagram [22].

ratio 0.292; 95\% CI 0.136-0.631; $p<0.001)$; Askling et al. [52] reported $20 \%$ of players experienced hamstring injuries in the intervention group and $67 \%$ in the control group $(p<0.05)$.

Two of the four trials reporting a statistically significant reduction in injury related to ankle injuries in those with history of injury, with proprioception training [55,56]. Mohammadi [55] reported a reduced risk of reinjury in a proprioception training intervention group (relative risk of injury 0.13 ; 95\% CI $0.003-0.93 ; p=0.02$ ) and no reduced risk in a strength training group (0.5; 95\% CI $0.11-1.87 ; p=0.27$ ). Tropp et al. [56] showed that significantly fewer of the proprioception intervention group experienced re-injuries (5\%) compared with the control group (25\%) $(p<0.01)$.

Four trials showed no statistically significant difference in injury incidence between control and exercise intervention groups $[12,51,53,54]$.

\section{Synthesis of results}

All trials were of high risk of bias and were not sufficiently homogenous for meta-analysis. When grouping trials according to injury type, two trials evaluated hamstring injuries, two trials evaluated ankle sprain reinjuries, and four trials were not comparable. No further analyses were conducted owing to differences in study design, intervention, and outcomes across the trials. The two hamstring trials used different interventions, duration of intervention period, and outcomes (injury definition), and also had differences in study design, notably with use of clustering [50,52]. The ankle trials were not comparable on intervention, outcomes (injury definition), and timing of outcomes $[55,56]$. A qualitative analysis was conducted.

\section{Risk of bias across studies}

Table 3 shows consistent components of risk of bias across the trials, including performance and detection bias due to inadequate blinding in all of the trials, and selection bias due to a lack of transparency regarding sequence generation in most trials [12,51,52,55,56] and of allocation concealment in all trials. There was a lack of blinding of outcome measurement, with evidence of injury registration being performed by personnel providing the intervention in all of the included trials in which the injury registration process is reported [12,50-54]. There were also issues regarding blinding of research staff, with staff visiting intervention groups during the study period in two of the trials $[52,55]$. Only one trial had a published protocol demonstrating pre-defined study goals [50], introducing a risk of selective reporting of outcomes in the other trials. Two trials were poorly reported, limiting accurate assessment of their internal validity [55,56]. A 
Table 2 Summary of trial characteristics

\begin{tabular}{|c|c|c|c|c|c|c|c|c|}
\hline $\begin{array}{l}\text { References } \\
\text { country }\end{array}$ & $\begin{array}{l}\text { Primary outcome } \\
\text { measure/means } \\
\text { of reporting }\end{array}$ & Participants & Intervention & $\begin{array}{l}\text { Follow-up } \\
\text { period }\end{array}$ & Compliance & $\begin{array}{l}\text { Effect of intervention } \\
(95 \% \mathrm{Cl})\end{array}$ & Conclusion & Comments \\
\hline $\begin{array}{l}\text { Askling et al. } \\
\text { [52] Sweden }\end{array}$ & $\begin{array}{l}\text { Time loss Injuries to } \\
\text { the hamstring\% Injury } \\
\text { occurrence }\end{array}$ & $\begin{array}{l}\text { IG: } 15 \text { CG: } \\
15 \text { Mean } \\
\text { age IG: } 24 \\
\text { CG: } 26\end{array}$ & $\begin{array}{l}10 \text { weeks preseason intervention } \\
\text { encompassing } 16 \text { sessions of } \\
\text { hamstring training using } \\
\text { concentric and eccentric actions, } \\
\text { after a standardized warm-up }\end{array}$ & $\begin{array}{l}1 \text { season of } \\
10 \text { months }\end{array}$ & NR & $\begin{array}{l}\text { IG 20\% CG 67\% Significantly } \\
\text { fewer injuries in the IG } \\
(p<0.05)\end{array}$ & $\begin{array}{l}\text { Eccentric hamstring } \\
\text { training may result in } \\
\text { a lower occurrence of } \\
\text { hamstring strains }\end{array}$ & $\begin{array}{l}\text { High injury rate in the } \\
\text { CG (67\%) No loss to FU }\end{array}$ \\
\hline $\begin{array}{l}\text { Engebretsen } \\
\text { et al. [12] } \\
\text { Norway }\end{array}$ & $\begin{array}{l}\text { Time loss Injuries to the } \\
\text { ankle, knee, groin, or } \\
\text { hamstring in high-risk } \\
\text { players Mean injury } \\
\text { Incidence per 1,000 h/RR) }\end{array}$ & $\begin{array}{l}\text { High-risk } \\
\text { players IG: } \\
193 \text { CG: } 195 \\
\text { Mean age } \\
\text { NR }\end{array}$ & $\begin{array}{l}\text { Progressive exercise program for } \\
\text { the ankle, knee, groin, and/or } \\
\text { hamstring } 3 \times \text { a week for } \\
10 \text { weeks then } \times 1 \text { a week for the } \\
\text { rest of the season }\end{array}$ & $\begin{array}{l}1 \text { season of } \\
7 \text { months }\end{array}$ & $\begin{array}{l}19-30 \% \\
\text { during the } \\
\text { preseason } \\
\text { intervention }\end{array}$ & $\begin{array}{l}\mathrm{IG}=4.9 \mathrm{CG}=5.3 \text { RR } 0.93 \\
(0.71-1.21) \text { This was NS } \\
(p=0.50)\end{array}$ & $\begin{array}{l}\text { The risk of injury in } \\
\text { players deemed at } \\
\text { higher risk was not } \\
\text { changed with a } \\
\text { targeted training } \\
\text { program }\end{array}$ & $\begin{array}{l}19 \text { of the } 31 \text { teams already } \\
\text { performed preventive } \\
\text { exercises in regular training } \\
\text { ITT analysis conducted } 3 \% \\
\text { players lost to FU }\end{array}$ \\
\hline $\begin{array}{l}\text { Fredberg } \\
\text { et al. [51] } \\
\text { Denmark }\end{array}$ & $\begin{array}{l}\text { All injuries to the Achilles } \\
\text { and/or patellar tendon\% } \\
\text { Injury risk/RD }\end{array}$ & $\begin{array}{l}\text { IG: } 98 \text { CG: } \\
\text { 146 Mean } \\
\text { age } 25\end{array}$ & $\begin{array}{l}\text { Eccentric exercise and stretching } \\
\text { program of Achilles and patellar } \\
\text { tendons All exercises performed } \\
\text { for } 10 \text { min } 3 \text { times a week }\end{array}$ & 12 months & 2.25/week & $\begin{array}{l}\text { Patella }=\text { RD 0\% }(p=1.0) \\
\text { Achilles = RD 2\% ( } p=0.86) \\
\text { These were NS }\end{array}$ & $\begin{array}{l}\text { Eccentric exercise had } \\
\text { no positive effects on } \\
\text { the risk of Achilles or } \\
\text { patella tendon injury }\end{array}$ & $\begin{array}{l}\text { CG 'allowed to continue } \\
\text { with the different types of } \\
\text { flexibility training that they } \\
\text { all used' No ITT analysis 17\% } \\
\text { team withdrawn }\end{array}$ \\
\hline $\begin{array}{l}\text { Hölmich } \\
\text { et al. [53] } \\
\text { Denmark }\end{array}$ & $\begin{array}{l}\text { All injuries to the groin } \\
\text { Time } \\
\text { to first groin injury/HR }\end{array}$ & $\begin{array}{l}\text { IG: } 524 \text { CG: } \\
453 \text { Mean } \\
\text { age IG: } 24 \\
\text { CG: } 25\end{array}$ & $\begin{array}{l}6 \text { exercises including hip } \\
\text { adduction and abdominal } \\
\text { strengthening, coordination and } \\
\text { stretching, 2-4 times a week }\end{array}$ & $\begin{array}{l}1 \text { season of } \\
10 \text { months }\end{array}$ & NR & $\begin{array}{l}\text { HR } 0.69(0.40-1.19) \text { This } \\
\text { was NS }(p=0.18)\end{array}$ & $\begin{array}{l}\text { Intervention resulted in } \\
\text { no significant reduction } \\
\text { in groin injury risk }\end{array}$ & $\begin{array}{l}\text { No ITT analysis Injured } \\
\text { players censored } 56 \% \text { teams } \\
\text { and } 7 \% \text { of remaining } \\
\text { players withdrawn }\end{array}$ \\
\hline $\begin{array}{l}\text { Mohammadi } \\
\text { [55] Unclear }\end{array}$ & $\begin{array}{l}\text { All ankle inversion sprain } \\
\text { re-injuries RR of injury per } \\
1,000 \mathrm{~h}\end{array}$ & $\begin{array}{l}\text { Each IG: } 20 \\
\text { CG: } 20 \\
\text { Mean age } \\
25\end{array}$ & $\begin{array}{l}\text { Progressive ankle disc training for } \\
30 \text { min daily (PT) Isometric and } \\
\text { dynamic specific evertor strength } \\
\text { training (ST). }\end{array}$ & $\begin{array}{l}1 \text { season } \\
\text { after injury }\end{array}$ & $N R$ & $\begin{array}{l}\text { PT - RR } 0.13 \\
\text { (0.003-0.93) significantly fewer } \\
\text { injuries in the IG }(p=0.02) \\
\text { ST - RR 0.5 }(0.11-1.87) \text { This } \\
\text { was NS }(p=0.27)\end{array}$ & $\begin{array}{l}\text { Progressive ankle disc } \\
\text { training may reduce } \\
\text { the risk of recurrent } \\
\text { ankle inversion injuries }\end{array}$ & $\begin{array}{l}\text { Information on much of the } \\
\text { study design is lacking No } \\
\text { ITT analyses No loss to FU }\end{array}$ \\
\hline $\begin{array}{l}\text { Petersen } \\
\text { et al. [50] } \\
\text { Denmark }\end{array}$ & $\begin{array}{l}\text { All hamstring injuries } \\
\text { Injury rates per } 100 \text { player } \\
\text { seasons/rate ratio }\end{array}$ & $\begin{array}{l}\text { IG: } 461 \text { CG: } \\
\text { 481 Mean } \\
\text { age IG: } 23 \\
\text { CG: } 24\end{array}$ & $\begin{array}{l}10 \text { weeks of progressive eccentric } \\
\text { hamstring training followed by a } \\
\text { weekly program }\end{array}$ & $\begin{array}{l}1 \text { season ( } 2 \text { half } \\
\text { seasons over } \\
12 \text { months) }\end{array}$ & $\begin{array}{l}91 \% \text { of the } \\
\text { initial } 27 \\
\text { sessions }\end{array}$ & $\begin{array}{l}\text { IG } 3.8 \text { CG } 13.1 \text { Rate ratio } \\
0.292(0.136-0.631) \text { Significantly } \\
\text { fewer injuries in the IG } \\
(p<0.001)\end{array}$ & $\begin{array}{l}\text { Additional eccentric } \\
\text { hamstring training } \\
\text { significantly reduced } \\
\text { the risk of hamstring } \\
\text { strain }\end{array}$ & $\begin{array}{l}\text { No ITT analysis } 7 \% \text { teams } \\
\text { and } 8 \% \text { of remaining } \\
\text { players withdrawn }\end{array}$ \\
\hline $\begin{array}{l}\text { Tropp et al. } \\
\text { [56] Sweden }\end{array}$ & $\begin{array}{l}\text { Time loss ankle sprains } \\
\text { in those with a history } \\
\text { of sprain\% Injury risk }\end{array}$ & $\begin{array}{l}\text { CG: } 75 \text { IG: } \\
65 \text { Mean } \\
\text { age NR }\end{array}$ & $\begin{array}{l}10 \text { min of ankle disc training } 5 \\
\text { times a week for } 10 \text { weeks. Then } \\
5 \text { min, } 3 \text { times a week }\end{array}$ & 6 months & $N R$ & $\begin{array}{l}\text { IG } 5 \% \text { CG } 25 \% \text { Significantly } \\
\text { fewer re-injuries in the IG } \\
(p<0.01)\end{array}$ & $\begin{array}{l}\text { In players with a history } \\
\text { of ankle sprain, ankle } \\
\text { disc training is indicated } \\
\text { to reduce the risk of } \\
\text { re-injury }\end{array}$ & $\begin{array}{l}\text { Information on key aspects } \\
\text { of study design lacking } \\
\text { No loss to FU }\end{array}$ \\
\hline $\begin{array}{l}\text { van } \\
\text { Beijsterveldt } \\
\text { et al. [54] } \\
\text { Holland }\end{array}$ & $\begin{array}{l}\text { All injury incidences Injury } \\
\text { incidence per 1,000 sports } \mathrm{h}\end{array}$ & $\begin{array}{l}\text { IG: } 223 \text { CG: } \\
233 \text { Mean } \\
\text { age IG: } 24 \\
\text { CG: } 25\end{array}$ & $\begin{array}{l}10 \text { exercises, used at each training } \\
\text { session, } 2 / 3 \text { times a week. Included } \\
\text { core stability, muscle strengthening, } \\
\text { proprioceptive, stabilization and } \\
\text { plyometric exercises }\end{array}$ & $\begin{array}{l}1 \text { season of } \\
9 \text { months }\end{array}$ & $\begin{array}{l}71 \% \text { player } \\
\text { compliance }\end{array}$ & $\begin{array}{l}\text { IG: } 9.6(8.4-11.0) \text { CG: } 9.7 \\
(8.5-11.1) \text { This was NS } \\
(p>0.05)\end{array}$ & $\begin{array}{l}\text { No significant differences } \\
\text { found in the overall } \\
\text { injury incidence or injury } \\
\text { severity between the IG } \\
\text { and CG }\end{array}$ & $\begin{array}{l}\text { No ITT analysis } 6 \% \text { players } \\
\text { lost to FU }\end{array}$ \\
\hline
\end{tabular}

CG control group, $C I$ confidence interval, FU follow-up, $H R$ hazard risk, IG intervention group, ITT intention-to-treat analysis, NR not reported, NS not significant, $R D$ risk difference, $R R$ relative risk, ST strength training, PT proprioceptive training. 
Table 3 Summary of risk of bias scores [20], reported in line with Rushton et al. [49]

\begin{tabular}{|c|c|c|c|c|c|c|c|c|}
\hline \multirow[t]{2}{*}{ References } & \multicolumn{6}{|c|}{ Components of risk of bias ${ }^{a}$} & \multirow[t]{2}{*}{ Overall } & \multirow[t]{2}{*}{ Comments, high-risk components } \\
\hline & 1 & 2 & 3 & 4 & 5 & 6 & & \\
\hline Askling et al. [52] & $U$ & U & $\mathrm{H}$ & $U$ & $U$ & U & High 1 Unclear 5 Low 0 & $\begin{array}{l}\text { High-risk components: } 1 \text { No participant, intervention provider, } \\
\text { or outcome assessor blinding }\end{array}$ \\
\hline Engebretsen et al. [12] & U & U & $\mathrm{H}$ & L & $U$ & U & High 1 Unclear 4 Low 1 & $\begin{array}{l}\text { High-risk components: } 1 \text { No participant, intervention provider, } \\
\text { or outcome assessor blinding }\end{array}$ \\
\hline Fredberg et al. [51] & U & U & $\mathrm{H}$ & $u$ & $U$ & U & High 1 Unclear 5 Low 0 & $\begin{array}{l}\text { High-risk components: } 1 \text { No participant, intervention provider, } \\
\text { or outcome assessor blinding }\end{array}$ \\
\hline Hölmich et al. [53] & $L$ & U & $\mathrm{H}$ & $u$ & $U$ & L & High 1 Unclear 3 Low 2 & $\begin{array}{l}\text { High-risk components: } 1 \text { No participant, intervention provider, } \\
\text { or outcome assessor blinding }\end{array}$ \\
\hline Mohammadi [55] & U & U & $U$ & L & $U$ & $\mathrm{H}$ & High 1 Unclear 4 Low 1 & $\begin{array}{l}\text { High-risk components: } 1 \text { Inadequate reporting of many aspects } \\
\text { of study design }\end{array}$ \\
\hline Petersen et al. [50] & $\mathrm{L}$ & U & $\mathrm{H}$ & L & $\mathrm{L}$ & L & High 1 Unclear 1 Low 4 & $\begin{array}{l}\text { High-risk components: } 1 \text { No participant, intervention provider, } \\
\text { or outcome assessor blinding }\end{array}$ \\
\hline Tropp et al. [56] & U & U & $U$ & L & $U$ & $\mathrm{H}$ & High 1 Unclear 4 Low 1 & $\begin{array}{l}\text { High-risk components: } 1 \text { Inadequate reporting of many aspects } \\
\text { of study design }\end{array}$ \\
\hline van Beijsterveldt et al. [54] & $L$ & U & $\mathrm{H}$ & L & $U$ & U & High 1 Unclear 3 Low 2 & $\begin{array}{l}\text { High-risk components: } 1 \text { Insufficient participant, intervention } \\
\text { provider, and outcome assessor blinding }\end{array}$ \\
\hline
\end{tabular}

${ }^{a}$ Components of risk of bias: 1 , random sequence generation; 2 , allocation concealment; 3 , blinding of participants, personnel, and outcome assessors; 4 , incomplete outcome data; 5 , selective reporting; 6 , other bias. Levels of risk of bias: $\mathrm{H}$, high risk of bias; $\mathrm{U}$, unclear risk of bias; $\mathrm{L}$, low risk of bias.

number of trials did not present complete outcome data, using available case analyses rather than including all randomized participants. Three of the trials had full data on all randomized subjects $[52,55,56]$ and one of the remaining trials conducted an ITT analysis [12]. A high rate of withdrawals introduced a risk of attrition bias to the trial by Hölmich et al. [53], and the reliability of several of the trials was impaired by low cohort sizes or evidence of insufficient power [50,52,55,56]. Compliance was poorly reported and, of the four trials in which compliance with at least part of the intervention is documented $[12,50,51,54]$, lower compliance than pre-defined targets was reported in two [12,51].

\section{Discussion}

\section{Summary of evidence}

This systematic review evaluated the efficacy of exercise for injury prevention in adult male football. The eight included trials, with 3,355 participants, used a range of exercise interventions and outcome measures. Disappointingly, despite a number of trials being recent, all trials were assessed as having a high risk of bias. Four trials demonstrated statistically significant reductions in the incidence of injury: two relating to hamstring strains and two relating to recurrent ankle sprains. These findings are of interest, given that hamstring and ankle injury are two areas most prone to injury in footballers $[5,57]$.

Hamstring strains are one of the most common injuries at professional football clubs, accounting for $12-16 \%$ of all injuries [5,39,58,59]. It is believed that they often occur during rapid eccentric loading when they are stretched beyond the optimal torque for generating tension, notably during sprinting [52,58,60]. It has been suggested that eccentric exercise increases this angle of optimal torque and may reduce the risk of injury [61-65]. There was some evidence demonstrating a reduction of the incidence of hamstring injury over the course of a season as an outcome of pre-season eccentric hamstring training, with two trials showing statistically significant reductions [50,52]. Although these findings are interesting, both trials were assessed as having a high risk of bias due to inadequate blinding, notably lacking blinding of staff registering injuries. The positive findings of these trials are consistent with those evaluating male athletes from different sports [66,67]; however, these trials are also of poor quality. These findings from trials with a high risk of bias demonstrate the need for an adequately powered trial with a low risk of bias to evaluate the efficacy of eccentric hamstring exercises on hamstring injury incidence. Future research should also consider whether participants have a history of injury, as both of the included trials demonstrated a reduction of hamstring injury recurrence with eccentric training [50,52]. Notably, Petersen et al. [50] demonstrated a significant reduction of approximately $85 \%$. This is particularly relevant given that previous injury is the greatest risk factor for hamstring strain [68] and that re-injuries cause longer absences from sport [5].

History of injury is also a key risk factor for other football injuries $[69,70]$, including ankle injuries, which account for $11 \%$ of injuries to footballers and have a high recurrence rate of up to $34 \%[38,71]$. The high risk of recurrence has been associated with impaired sensorimotor function after injury in the form of proprioceptive deficits, such as muscle reaction timing [72]. Balancing exercises are purported to improve these deficits [73]. There was some evidence of reduced incidence of ankle 
sprain re-injury as an outcome of balancing exercises using an unstable surface, with two trials showing statistically significant reductions $[55,56]$. Although these findings are interesting, the trials were assessed as having a high risk of bias due to poor reporting. There is not sufficient evidence to reach a clear conclusion regarding the efficacy of proprioceptive training on ankle injury recurrence in adult male football. An adequately powered trial with a low risk of bias is required, particularly considering a recent meta-analysis including male and female, athletic and non-athletic populations that found no statistically significant difference in risk of ankle re-injury with proprioceptive training [74].

Four trials, each evaluating different injuries, were unable to provide evidence of efficacy of exercise intervention for injury prevention, with each reporting no statistically significant benefit. One of these trials identified footballers at increased risk of injury, but the targeted exercise intervention did not reduce the incidence of common football injuries [12]. A major limitation of this trial was low compliance with the intervention (19-30\%), which increased the risk of type II error. Groin injuries are common in football and can lead to prolonged periods away from play, hence a program to reduce the risk of groin injury could be of great benefit to football clubs [40]. However, the trial by Hölmich et al. [53] that evaluated a groin injury prevention program also showed no statistically significant effect on injury incidence. One further trial did not provide support for the prophylactic use of eccentric exercise for preventing Achilles or patellar tendon injuries [51], despite some evidence supporting the use of eccentric exercise for the treatment of tendon injuries [75]. A further finding was that a general injury prevention program evaluated in the trial by van Beijsterveldt et al. [54], which included a range of exercises in the form of a warm-up, did not show statistically significant effects on injury incidence over a season. Their finding of no effect on overall injury incidence was similar to the findings of trials using the same program, 'The 11' or the modified version 'The 11+' in adolescent female football players $[76,77]$.

The key finding of this review is that, based on the current level of evidence, it is not possible to evaluate whether exercise is efficacious in the prevention of injuries in adult male football. A lack of high-quality RCTs of injury prevention in the adult male football population is contradictory to the number of publications on injury epidemiology and risk factors in this population. The findings are similar to those of van Beijsterveldt et al. [24], who reviewed general exercise programs for injury prevention in footballers, finding conflicting and weak evidence to support their use. However, the findings are in contrast to the systematic review by Kirkendall and Dvorak [21], which uses findings, including those from studies with male participants, to support the use of a range of exercises in an injury-prevention program. The latter review demonstrates a number of methodological flaws; hence, the findings must be extrapolated with caution. Findings of this review also contrast with those in adolescent female footballers, where positive effects of neuromuscular exercise programs on injury incidence have been found [17]. This could be due to a number of reasons, including a difference in the intervention type or compliance, or a disparity in the quantity and quality of research. It could also be due to age- or sex-related differences in study participants [28,29]. It is possible that neuromuscular programs are more effective in reducing the risk of injury in female footballers because they address neuromuscular imbalances and movement patterns that have been associated with an increased risk of severe injury, such as ACL rupture, in females [28,78]. Corresponding with this, it has been suggested that programs designed to target gender-related differences in injury risk and incidence may be warranted [28].

Two definitions of injury were used by the trials, either 'any injury' or 'time loss injury', both of which correspond with those recommended by the consensus statement published in 2006 by Fuller et al. [79]. Consensus should be found regarding the use of specific outcome measures, such as injury definition, which would allow the use of data pooling in the future. Wider reporting of injury severity and duration of time loss from football would also benefit future research in this field, allowing the impact of injuries to be assessed. Also, incidence of adverse effects should be more widely reported, as demonstrated by the findings of Fredberg et al. [51] where, contrary to expectation, eccentric exercise increased patella tendon injury incidence in footballers with degenerate tendons.

\section{Strengths and limitations}

Strengths of this review are its rigorous methodology based on a pre-defined protocol. Its main limitation was the finding of poor reporting of included trials and high risk of bias components. These findings are particularly disappointing considering a number of trials were published after the Consolidated Standards of Reporting Trials (CONSORT) statement, which supports explicit reporting of trials $[80,81]$. High risk of bias components included randomization and concealment of allocation, processes that, if inadequately performed, may lead to an overestimation of treatment effect $[82,83]$. The nature of the interventions may preclude blinding of the participants; however, this also introduced a risk of bias, particularly with the use of subjective measures such as self-reporting of injury [84] as used in the trials by Askling et al. [52] and Fredberg et al. [51]. There was also little evidence of predefined outcomes, partly due to a lack of published 
protocols. Issues relating to compliance are also notable, as direct correlations between compliance and the efficacy of injury prevention programs have been found [85].

Using GRADE [86] (the Grading of Recommendations Assessment, Development and Evaluation system), based on the eight trials included in the qualitative synthesis, the quality of evidence evaluating the efficacy of exercise intervention on injury prevention in adult male football was 'very low'. This level of evidence is defined as "very little confidence in the effect estimate: the true effect is likely to be substantially different from the estimate of effect" [86]. The quality of evidence was downgraded due to high risk of bias, inconsistent results, indirectness of evidence, and imprecision [86].

\section{Conclusions}

This rigorous systematic review has identified very lowquality evidence on the efficacy of exercise on prevention of injuries in adult male football. There is some support for the use of eccentric hamstring exercise for hamstring injury prevention and proprioceptive training to reduce the incidence of recurrent ankle sprains; however, sufficient evidence is lacking to reach a clear conclusion regarding their efficacy. There is a need for low risk of bias, comprehensively reported and properly powered trials evaluating the efficacy of generic and specific exercise interventions for injury prevention. Notable areas of future research may relate to the prevention of ankle and hamstring injuries. Future research should also be considered regarding the efficacy of exercise in preventing groin injuries and knee sprains, for these are also major injury burdens in male adult football and lack high-quality trials evaluating efficacy of preventive interventions $[4,5,12,69]$.

\section{Acknowledgments}

Tom Porter and Dr Alison Rushton declare that they have no conflicts of interest. The authors gratefully acknowledge the assistance of reviewer David Hunt for his contributions. No financial support was received for the conduct of this study or preparation of this manuscript.

Received: 6 June 2014 Accepted: 21 October 2014

Published online: 20 January 2015

\section{References}

1. FIFA. FIFA Big Count 2006: 270 million people active in football. FIFA, Zurich. 2008. http://www.fifa.com/mm/document/fifafacts/bcoffsurv/bigcount. statspackage_7024.pdf. Accessed 16 Feb 2013.

2. Parry $L$, Drust B. Is injury the major cause of elite soccer players being unavailable to train and play during the competitive season? Phys Ther Sport. 2006: 7(2):58-64.

3. Schmikli SL, Backx FJ, Kemler HJ, van Mechelen W. National survey on sports injuries in the Netherlands: target populations for sports injury prevention programs. Clin J Sports Med. 2009; 19(2):101-06.

4. Ekstrand J, Hägglund M, Kristenson K, Magnusson H, Waldén M. Fewer ligament injuries but no preventive effect on muscle injuries and severe injuries: an 11-year follow-up of the UEFA Champions League injury study. Br J Sports Med. 2013. doi:10.1136/bjsports-2013-092394.

5. Ekstrand J, Hägglund $M$, Waldén $M$. Injury incidence and injury patterns in professional football: the UEFA injury study. $\mathrm{Br} /$ Sports Med. 2011; 45(7):553-58.
6. Hägglund M, Waldén M, Magnusson $H$, Kristenson $K$, Bengtsson H, Ekstrand J. Injuries affect team performance negatively in professional football: an 11-year follow-up of the UEFA Champions League injury study. Br J Sports Med. 2013. doi:10.1136/bjsports-2013-092215.

7. van Beijsterveldt AMC, Krist MR, Schmikli SL, Stubbe JH, de Wit GA, Inklaar H, et al. Effectiveness and cost-effectiveness of an injury prevention programme for adult male amateur soccer players: design of a cluster-randomised controlled trial. Inj Prev. 2011. doi:10.1136/ip.2010.027979.

8. Woods C, Hawkins R, Hulse M, Hodson A. The football association medical research programme: an audit of injuries in professional footballanalysis of preseason injuries. Br J Sports Med. 2002; 36(6):436-41.

9. Appaneal RN, Levine BR, Perna FM, Roh JL. Measuring postinjury depression among male and female competitive athletes. J Sport Exerc Psychol. 2009; 31(1):60-76.

10. Mujika I, Padilla S. Detraining: loss of training-induced physiological and performance adaptations. Part II: long term insufficient training stimulus. Sports Med. 2000; 30(3):145-54.

11. Myklebust $G$, Bahr R. Return to play guidelines after anterior cruciate ligament surgery. Br J Sports Med. 2005; 39(3):127-31.

12. Engebretsen AH, Myklebust G, Holme I, Engebretsen L, Bahr R. Prevention of injuries among male soccer players: a prospective, randomized intervention study targeting players with previous injuries or reduced function. Am J Sports Med. 2008; 36(6):1052-60.

13. Hewett TE, Lindenfeld TN, Riccobene JV, Noyes FR. The effect of neuromuscular training on the incidence of knee injury in female athletes. A prospective study. Am J Sports Med. 1999; 27(6):699-706.

14. Mandelbaum BR, Silvers HJ, Watanabe DS, Knarr JF, Thomas SD, Griffin LY, et al. Effectiveness of a neuromuscular and proprioceptive training program in preventing anterior cruciate ligament Injuries in female athletes. Am J Sports Med. 2005; 33(7):1003-10.

15. Heidt RS, Sweeterman LM, Carlonas RL, Traub JA, Tekulve FX. Avoidance of soccer injuries with preseason conditioning. Am J Sports Med. 2000; 28(5):659-62.

16. Gilchrist J, Mandelbaum BR, Melancon H, Ryan GW, Silvers HJ, Griffin LY, et al. A randomized controlled trial to prevent noncontact anterior cruciate ligament injury in female collegiate soccer players. Am J Sports Med. 2008; 36(8):1476-83.

17. Grindstaff $T L$, Hammill RR, Tuzson AE, Hertel J. Neuromuscular control training programs and noncontact anterior cruciate ligament injury rates in female athletes: a numbers-needed-to-treat analysis. J Ath/ Train. 2006; 41(4):450-56.

18. Sadoghi $P$, von Keudell A, Vavken P. Effectiveness of anterior cruciate ligament injury prevention training programs. J Bone Jt Surg Am. 2012; 94(9):769-76.

19. Caraffa A, Cerulli G, Projetti M, Aisa G, Rizzo A. Prevention of anterior cruciate ligament injuries in soccer. A prospective controlled study of proprioceptive training. Knee Surg Sports Traumatol Arthrosc. 1996; 4(1):19-21.

20. Higgins J, Green S. Cochrane handbook for systematic reviews of interventions version 5.0.2 [updated September 2009]. The Cochrane Collaboration. 2009. http://www.cochrane-handbook.org. Accessed 31 March 2013

21. Kirkendall DT, Dvorak J. Effective injury prevention in soccer. Phys Sportsmed. 2010; 38(1):147-57.

22. Moher D, Liberati A, Tetzlaff J, Altman DG. Preferred reporting items for systematic reviews and meta-analyses: the PRISMA statement. BMJ. 2009. doi:10.1136/bmj.b2535.

23. Liberati A, Altman DG, Tetzlaff J, Mulrow C, Gøtzsche PC, loannidis JPA, et al. The PRISMA statement for reporting systematic reviews and meta-analyses of studies that evaluate healthcare interventions: explanation and elaboration. BMJ. 2009. doi:10.1136/bmj.b2700.

24. van Beijsterveldt AMC, Horst N, Port IL, Backx FJ. How effective are exercise-based injury prevention programmes for soccer players? Sports Med. 2013; 43(4):257-65.

25. Prodromos CC, Han Y, Rogowski J, Joyce B, Shi K. A meta-analysis of the incidence of anterior cruciate ligament tears as a function of gender, sport, and a knee injury-reduction regimen. Arthroscopy. 2007; 23(12):1320-25.

26. Waldén $M$, Hägglund $M$, Werner J, Ekstrand J. The epidemiology of anterior cruciate ligament injury in football (soccer): a review of the literature from a gender-related perspective. Knee Surg Sports Traumatol Arthrosc. 2011; 19(1):3-10. 
27. Arendt EA, Agel J, Dick R. Anterior cruciate ligament injury patterns among collegiate men and women. J Ath/ Train. 1999; 34(2):86-92.

28. Hewett TE, Ford KR, Hoogenboom BJ, Myer GD. Understanding and preventing $A C L$ injuries: current biomechanical and epidemiologic considerations-update 2010. N Am J Sports Phys Ther. 2010; 5(4):234-51.

29. Alentorn-Geli E, Myer GD, Silvers HJ, Samitier G, Romero D, Lazaro-Haro C, et al. Prevention of non-contact anterior cruciate ligament injuries in soccer players. Part 1: mechanisms of injury and underlying risk factors. Knee Surg Sports Traumatol Arthrosc. 2009; 17(7):705-29.

30. Smith HC, Vacek $P$, Johnson RJ, Slauterbeck JR, Hashemi J, Shultz $S$, et al. Risk factors for anterior cruciate ligament injury: a review of the literature: part 2: hormonal, genetic, cognitive function, previous injury, and extrinsic risk factors. Sports Health. 2012; 4(2):155-61.

31. Smith HC, Vacek P, Johnson RJ, Slauterbeck JR, Hashemi J, Schultz S, et al. Risk factors for anterior cruciate ligament injury: a review of the literature: part 1: neuromuscular and anatomic risk. Sports Health. 2012; 4(1):69-78

32. Hagglund $M$, Walden $M$, Ekstrand J. Injuries among male and female elite football players. Scand J Med Sci Sports. 2009; 19(6):819-27.

33. Junge A, Dvorak J. Injury surveillance in the world football tournaments 1998-2012. Br J Sports Med. 2013. doi:10.1136/bjsports-2013-092205.

34. Tacconelli E. Systematic reviews: CRD's guidance for undertaking reviews in health care. Lancet Infect Dis. 2010; 10(4):226

35. Egger M, Zellweger-Zähner T, Schneider M, Junker C, Lengeler C, Antes G. Language bias in randomised controlled trials published in English and German. Lancet. 1997; 350(9074):326-29.

36. Vickers A, Goyal N, Harland R, Rees R. Do certain countries produce only positive results? A systematic review of controlled trials. Control Clin Trials. 1998; 19(2):159-66.

37. FIFA. Laws of the Game 2013/2014. FIFA, Zurich. 2013. http://www.fifa.com/ $\mathrm{mm} /$ document/footballdevelopment/refereeing/81/42/36/log2013en_ neutral.pdf. Accessed 09 Oct 2013.

38. Woods C, Hawkins R, Hulse M, Hodson A. The football association medical research programme: an audit of injuries in professional football: an analysis of ankle sprains. Br J Sports Med. 2003; 37(3):233-38.

39. Hawkins RD, Hulse MA, Wilkinson C, Hodson A, Gibson M. The association football medical research programme: an audit of injuries in professional football. Br J Sports Med. 2001; 35(1):43-7.

40. Werner J, Hägglund M, Waldén M, Ekstrand J. UEFA injury study: a prospective study of hip and groin injuries in professional football over seven consecutive seasons. Br J Sports Med. 2009; 43(13):1036-40.

41. Ekstrand J, Hagglund M, Walden M. Epidemiology of muscle injuries in professional football (soccer). Am J Sports Med. 2011; 39(6):1226-32.

42. Knowles SB, Marshall SW, Guskiewicz KM. Issues in estimating risks and rates in sports injury research. J Athl Train. 2006; 41(2):207-15.

43. Furlan AD, Pennick V, Bombardier C, van Tulder M. 2009 updated method guidelines for systematic reviews in the Cochrane Back Review Group. Spine. 2009; 34(18):1929-41.

44. Cohen J. A coefficient of agreement for nominal scales. Educ Psychol Meas. 1960; 20(1):37-46.

45. Landis JR, Koch GG. The measurement of observer agreement for categorical data. Biometrics. 1977; 33(1):159-74.

46. Fisher $L$, Dixon D, Herson J, Frankwski R, Hearron M, Peace K. Intention to treat in clinical trials. In: Peace K, editor. Statistical issues in drug research and development. New York: Marcel Dekker; 1990: p. 331-50.

47. Heritier SR, Gebski VJ, Keech AC. Inclusion of patients in clinical trial analysis: the intention-to-treat principle. Med J Aust. 2003; 179(8):438-40

48. Jüni $P$, Witschi $A$, Bloch $R$, Egger $M$. The hazards of scoring the quality of clinical trials for meta-analysis. JAMA. 1999; 282(11):1054-60.

49. Rushton A, Wright C, Heneghan N, Eveleigh G, Calvert M, Freemantle N. Physiotherapy rehabilitation for whiplash associated disorder II: a systematic review and meta-analysis of randomised controlled trials. BMJ. 2011. doi:10.1136/bmjopen-2011-000265.

50. Petersen J, Thorborg K, Nielsen MB, Budtz-Jorgensen E, Holmich P. Preventive effect of eccentric training on acute hamstring injuries in men's soccer: a cluster-randomized controlled trial. Am J Sports Med. 2011; 39(11):2296-303.

51. Fredberg $U$, Bolvig L, Andersen NT. Prophylactic training in asymptomatic soccer players with ultrasonographic abnormalities in Achilles and patellar tendons: the Danish Super League Study. Am J Sports Med. 2008; 36(3):451-60.
52. Askling C, Karlsson J, Thorstensson A. Hamstring injury occurrence in elite soccer players after preseason strength training with eccentric overload. Scand J Med Sci Sports. 2003; 13(4):244-50.

53. Hölmich H, Larsen P, Krogsgaard K, Gluud C. Exercise program for prevention of groin pain in football players: a cluster randomized trial. Scand J Med Sci Sports. 2010; 20(6):814-21.

54. van Beijsterveldt AMC, van de Port IGL, Krist MR, Schmikli SL, Stubbe JH,

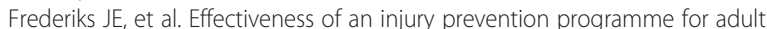
male amateur soccer players: a cluster-randomised controlled trial. $\mathrm{Br} J$ Sports Med. 2012. doi:10.1136/bjsports-2012-091277

55. Mohammadi F. Comparison of 3 preventive methods to reduce the recurrence of ankle inversion sprains in male soccer players. Am J Sports Med. 2007; 35(6):922-26.

56. Tropp H, Askling C, Gillquist J. Prevention of ankle sprains. Am J Sports Med. 1985; 13(4):259-62.

57. Inklaar H. Soccer injuries. I: incidence and severity. Sports Med. 1994; 18(1):55-73

58. Woods C, Hawkins RD, Maltby S, Hulse M, Thomas A, Hodson A. The football association medical research programme: an audit of injuries in professional football-analysis of hamstring injuries. Br J Sports Med. 2004; 38(1):36-41.

59. Arnason A, Andersen TE, Holme I, Engebretsen L, Bahr R. Prevention of hamstring strains in elite soccer: an intervention study. Scand J Med Sci Sports. 2008; 18(1):40-8.

60. Arnason A, Gudmundsson A, Dahl HA, Johannsson E. Soccer injuries in Iceland. Scand J Med Sci Sports. 1996; 6(1):40-5.

61. Brughelli $M$, Cronin J. Preventing hamstring injuries in sport. Strength Cond J. 2008; 30(1):55-64.

62. Mendiguchia J, Brughelli M. A return-to-sport algorithm for acute hamstring injuries. Phys Ther Sport. 2011; 12(1):2-14.

63. Brockett $\mathrm{CL}$, Morgan $\mathrm{DL}$, Proske U. Predicting hamstring strain injury in elite athletes. Med Sci Sports Exerc. 2004; 36(3):379-87.

64. Proske U, Morgan DL, Brockett $C L$, Percival P. Identifying athletes at risk of hamstring strains and how to protect them. Clin Exp Pharmacol Physiol. 2004; 31(8):546-50.

65. Brughelli M, Cronin J. Altering the length-tension relationship with eccentric exercise: implications for performance and injury. Sports Med. 2007; 37(9):807-26.

66. Gabbe BJ, Branson R, Bennell KL. A pilot randomised controlled trial of eccentric exercise to prevent hamstring injuries in community-level Australian Football. J Sci Med Sport. 2006; 9(1-2):103-09.

67. Brooks JHM, Fuller CW, Kemp SPT, Reddin DB. Incidence, risk, and prevention of hamstring muscle injuries in professional rugby union. Am J Sports Med. 2006; 34(8):1297-306.

68. Mendiguchia J, Alentorn-Geli E, Brughelli M. Hamstring strain injuries: are we heading in the right direction? Br J Sports Med. 2011. doi:10.1136/ bjsm.2010.081695.

69. Hägglund M, Waldén M, Ekstrand J. Risk factors for lower extremity muscle injury in professional soccer: the UEFA injury study. Am J Sports Med. 2013; 41(2):327-35.

70. Arnason A, Sigurdsson SB, Gudmundsson A, Holme I, Engebretsen L, Bahr R. Risk factors for injuries in football. Am J Sports Med. 2004; 32(1 suppl):5S-16S

71. van Rijn RM, van Os AG, Bernsen RM, Luijsterburg PA, Koes BW, Bierma-Zeinstra SM. What is the clinical course of acute ankle sprains? A systematic literature review. Am J Med. 2008; 121(4):324-31.

72. Munn J, Sullivan SJ, Schneiders AG. Evidence of sensorimotor deficits in functional ankle instability: a systematic review with meta-analysis. J Sci Med Sport. 2010; 13(1):2-12.

73. Osborne MD, Chou LS, Laskowski ER, Smith J, Kaufman KR. The effect of ankle disk training on muscle reaction time in subjects with a history of ankle sprain. Am J Sports Med. 2001; 29(5):627-32.

74. Postle K, Pak D, Smith TO. Effectiveness of proprioceptive exercises for ankle ligament injury in adults: a systematic literature and meta-analysis. Man Ther. 2012; 17(4):285-91.

75. Rees JD, Wolman RL, Wilson A. Eccentric exercises; why do they work, what are the problems and how can we improve them? Br J Sports Med. 2009; 43(4):242-46.

76. Steffen K, Myklebust G, Olsen OE, Holme I, Bahr R. Preventing injuries in female youth football-a cluster-randomized controlled trial. Scand J Med Sci Sports. 2008; 18(5):605-14. 
77. Soligard T, Myklebust G, Steffen K, Holme I, Silvers H, Bizzini M, et al. Comprehensive warm-up programme to prevent injuries in young female footballers: cluster randomised controlled trial. BMJ. 2008; 337:a2469.

78. Alentorn-Geli E, Myer G, Silvers H, Samitier G, Romero D, Lázaro-Haro C, et al. Prevention of non-contact anterior cruciate ligament injuries in soccer players. Part 2: a review of prevention programs aimed to modify risk factors and to reduce injury rates. Knee Surg Sports Traumatol Arthrosc. 2009; 17(8):859-79.

79. Fuller CW, Ekstrand J, Junge A, Andersen TE, Bahr R, Dvorak J, et al. Consensus statement on injury definitions and data collection procedures in studies of football (soccer) injuries. Br J Sports Med. 2006; 40(3):193-201.

80. Altman DG, Schulz KF, Moher D, Egger M, Davidoff F, Elbourne D, et al. The revised CONSORT statement for reporting randomized trials: explanation and elaboration. Ann Intern Med. 2001; 134(8):663-94.

81. Moher D, Schulz KF, Altman DG. The CONSORT statement: revised recommendations for improving the quality of reports of parallel-group randomised trials. Lancet. 2001; 357(9263):1191-94.

82. Schulz KF, Chalmers I, Hayes RJ, Altman DG. Empirical evidence of bias. Dimensions of methodological quality associated with estimates of treatment effects in controlled trials. JAMA. 1995; 273(5):408-12.

83. Moher D, Pham B, Jones A, Cook DJ, Jadad AR, Moher M, et al. Does quality of reports of randomised trials affect estimates of intervention efficacy reported in meta-analyses? Lancet. 1998; 352(9128):609-13.

84. Wood L, Egger M, Gluud LL, Schulz KF, Jüni P, Altman DG, et al. Empirical evidence of bias in treatment effect estimates in controlled trials with different interventions and outcomes: meta-epidemiological study. BMJ. 2008; 336(7644):601-05.

85. Soligard T, Nilstad A, Steffen K, Myklebust G, Holme I, Dvorak J, et al. Compliance with a comprehensive warm-up programme to prevent injuries in youth football. Br J Sports Med. 2010; 44(11):787-93.

86. Balshem H, Helfand M, Schünemann HJ, Oxman AD, Kunz R, Brozek J, et al. Rating the quality of evidence. J Clin Epidemiol. J Clin Epidemiol. 2011; 64(4):401-06.

\section{Submit your manuscript to a SpringerOpen ${ }^{\odot}$ journal and benefit from:}

- Convenient online submission

- Rigorous peer review

- Immediate publication on acceptance

- Open access: articles freely available online

- High visibility within the field

- Retaining the copyright to your article

Submit your next manuscript at $>$ springeropen.com 